\title{
Not So Simple: Integrating New Research Into Textbooks
}

\author{
JEFFREY E. STAMBAUGH \\ Midwestern State University \\ CHRISTINE QUINN TRANK \\ Texas Tech University
}

\begin{abstract}
Textbooks have been described as vehicles through which research is transferred to future practitioners. However, the sociology of scientific knowledge suggests that textbooks are not simply collected accounts of discrete "findings," but rather represent a highly stable and institutionalized pedagogy. The question then becomes, to what extent are new areas of research that have gained traction in the academic literature moved into textbooks, particularly when that research would introduce a new paradigm to a coherent pedagogical story? To explore this question, we examine textbooks to uncover the extent and manner of integration of recent research using institutional theory to study topics in strategic management. Finding significant variation in integration among textbooks, we discuss factors that can explain this variation and suggest avenues for systematic, theory-driven research on the textbook.
\end{abstract}

"I remember my first day as a teaching assistant in front of a class of 150 students. I had no training, many years had passed since I took that first general course, and I needed every ounce of help I could get. The text and the instructors' manual were my foundation, the rock on which I built my course. Correctly or not, they defined the field for my students-and for me." -Ballentine, 1988: 409

In the Structure of Scientific Revolutions, Thomas Kuhn (1970) argued that the textbook plays an essential role in science and in academic disciplines. He asserted that textbooks are the primary pedagogic method for embodying what is known about a field and are the tools of socialization into a profession and practice. More recently, scholars studying the sociology of scientific knowledge describe textbooks as "intrinsically important to the constitution and maintenance of a discipline" (Lynch \& Bogen, 1997: 482). Apple (2001: 282) describes the textbook as an important educational and cultural artifact:

We thank Roy Suddaby for his invaluable contributions to this paper, and also the three anonymous reviewers and Associate Editor Bettina Büchel for their encouragement and assistance.
It embodies the visions of legitimate knowledge of identifiable groups of people. In most cases it also becomes the "real curriculum" that is filtered through the lived culture of teachers and students as they go about their daily lives in classrooms.

The power of the textbook to define a discipline's pedagogy warrants increased attention to the production of textbooks and to their effects. Considering that students perceive that about $55 \%$ of their college-based knowledge comes from textbooks (Lichtenberg, 1992), the textbook may be one of the most underexamined pedagogical tools in the instructional repertoire. Most recently, the textbook has emerged as an important concern in the field of management as well, characterized as a vehicle through which research is transferred to future practitioners (Rousseau, 2006; Rousseau \& McCarthy, 2007). The belief that more recent research is not being integrated into textbooks is the focus of much of this concern, but it has been accompanied by little systematic research on what textbook content is or should be. A notable exception is Miner's (2003) study in which he asked scholars in the field of organization studies to rate the importance of major theories and then analyzed their validity and usefulness. A major purpose of that 
study was to raise questions about what should and should not be included in textbooks.

However, the description of the textbook as a cultural artifact directs our attention to the socially constructed nature of disciplinary pedagogy and the role of the textbook as a repository of meaning systems. Textbooks are viewed as idealizations of the science they describe (Kuhn, 1970; Shapin, 1995). In other words, textbooks are not simply collected accounts of discrete "findings." They present a coherent, thematically integrated view of a discipline and are part of "a stable, highly standardized, and widely disseminated disciplinary pedagogy" (Lynch \& Bogen, 1997: 482). Authors report a commitment to preserving a coherent story as well as conveying relevant academic research (Cameron, Ireland, Lussier, New, \& Robbins, 2003). Their testimony affirms Kuhn's (1970) argument that the creation and choice of textbook content is purposive; however, textbook content and theoretical commitments are often highly institutionalized and become so early in the construction of a field (Rotfeld, 2000).

The question then becomes, "to what extent are new areas of research that have gained traction in the academic literature moved into textbooks if their content is highly institutionalized, particularly when that research would introduce a new theme to a coherent pedagogical story?" To answer this question we focus on strategic management textbooks and the growing, but well-established, body of research in the academic literature employing institutional theory to explore key questions in strategy. The choice of this empirical case is driven by the divergent histories of strategy and institutional theory. Institutional theory was not influential in the earliest work in strategic management, and was, instead, viewed as inconsistent with strategy's imperatives. While strategic management as a field was being constructed and its pedagogical narrative was being developed, institutional theory was discounting managerial volition, which was central to strategy (Hambrick \& Chen, 2008). However, shifts in the research focus of many institutional scholars, as well as changing conditions in the environment of organizations that have created a new awareness of the importance of institutions to strategic management practice and research have brought the two perspectives together in the academic literature. In this study we examine the extent to which this ropprochement in the literature is reflected in textbooks. In the following sections, we briefly explore the increasing overlap between institutional theory and strategy and motivate our analysis of institutional coverage in strategic management texts. A de- scription of our methods for discovering institutional content follows. We conclude with a discussion of our results and suggest new directions for pedagogical research informed by work in the sociology of scientific knowledge.

\section{RAPPROCHEMENT: STRATEGIC MANAGEMENT AND INSTITUTIONAL THEORY}

It is clear that any number of research developments and many disciplines' textbooks could be candidates for exploring the integration of new research. There are, however, several reasons why the "particularly pronounced growth" (Greenwood, Oliver, Sahlin, \& Suddaby, 2008: 28) of studies applying institutional theory to strategy questions make the strategic management textbook an especially appropriate choice. These include the relatively well-defined historical understanding of the field of strategic management that did not, as it was developing, include institutional theory; new directions taken in institutional theory in the last several years focusing on interest and agency; and the growing recognition of the importance of institutions and institutional arrangements in strategy. We review each in the following sections.

\section{The Social Construction of Strategic Management and Institutional Theory}

As the field of strategy marked its roughly 30 years as a discipline, a number of studies surfaced that explore its evolution and content domain (Hambrick \& Chen, 2008; Hoskisson, Hitt, Wan, \& Yiu, 1999; Nerur, Rasheed, \& Natarajan, 2008; RamosRodríguez \& Ruíz-Navarro, 2004). These reviews have created a relatively clear picture of the social and academic roots of strategic management, as well as the thematic consensus. From a text analysis of the abstracts of 385 articles identified as falling in the domain of strategic management, Nag, Hambrick, and Chen (2007) developed the following definition:

The field of strategic management deals with (a) the major intended and emergent initiatives (b) taken by general managers on behalf of owners, (c) involving utilization of resources (d) to enhance the performance (e) of firms (f) in their external environments.

Textbooks describe strategic management in much the same way. Thompson, Gamble, and Strickland (2006: 3) define strategy as: "the competitive moves and business approaches that managers employ to grow the business, stake out a mar- 
ket position, attract and please customers, compete successfully, conduct operations, and achieve targeted objectives." Strategy is about "commitments, decisions, and actions" (Hitt, Ireland, \& Hoskisson, 2009: 6), but these activities are also getting tougher as "the pace of change is relentless and increasing" (Hitt et ol., 2009: 6). The textbook definitions share with the research literature a clear focus on managers engaging in action aimed at achieving organizational success, artfully coping with environmental exigencies.

In contrast, institutional theory's fundomental research question is "why and with what consequences do organizations exhibit particular organizational arrangements that defy traditional rational explanation?" (Greenwood et al., 2008: 7). Scott (2007: 460) describes institutional theory as concerned with relatively enduring and stable social structures:

$[P]$ rocesses by which structures, including schemas, rules, norms, and routines, become established as authoritative guidelines for social behavior. It inquires into how these elements are created, diffused, adopted, and adapted over space and time; and how they fall into decline and disuse. Although the ostensible subject is stability and order in social life, students of institutions must perforce attend not just to consensus and conformity but to conflict and change in social structures.

Although this definition suggests that institutions frame and enable managerial action, and it clearly implies a role for organizations in creating and disrupting institutions, early characterizations of institutional influences "assumed an overly deterministic causality and an overly unified institutional framework" (Scott \& Davis, 2007: 265), emphasizing constraints on behavior and downplaying the dynamics of institutions.

These early characterizations occurred at roughly the same time strategic management was forming as a relatively coherent discipline. Hambrick and Chen (2008: 42) point out that one reason scholars in organization theory were less central to the development of the field of strategic management was that during the period in which strategic management was being established (1978-1985) organization theory was "leaning away from managerial volition" with its focus on population ecology and institutional theory. Although a number of organization theories (e.g., power, decision making, organizational learning, and contingency theory) had an impact on strategy research as it developed, institutional theory had little play in strategy
(Nerur et al., 2008; Ramos-Rodríguez \& RuízNavarro, 2004). Certainly strategy research and theorizing using on institutional lens were being done (e.g., Chen \& Hambrick, 1995; Deephouse, 1999; Leblebici, Salancik, Copay, \& King, 1991; Oliver, 1991, 1997; Rao, 1994), but citations of authors and papers did not reach a level of citations (for Nerur et al., 2008, for example, 100 author citations between 1980 and 2000) for institutional theory to show up as influential in the bibliometric studies that covered the period of strategy's institutionalization (1980-2000; Nerur et al., 2008; RamosRodríguez \& Ruíz-Navarro, 2004).

During that formative period, however, the intellectual structure of the field went through a number of changes (Nerur et al., 2008; Ramos-Rodríguez \& Ruíz-Navarro, 2004), and the field continues to change. Two conditions emerged beginning in the 1990s that brought research in strategy and institutionalism together. First, the theoretical and empirical interests of institutional theorists increasingly recognized interest and purposive action (Lawrence \& Suddaby, 2006), and, as institutional theory became less characterized as focused on external constraint on managerial action, strategy researchers saw the possibilities in institutional analysis. "Suddenly," observe Scott and Davis (2007: 265), "it became clear that here was something else for managers to manage!" Second, significant changes in the strategic environment of organizations brought the utility of institutional theory into sharp relief for strategy researchers. We review these two developments in the next sections.

\section{Expansion and Change of Focus in Institutional Research}

The new research emphasis in institutional theory that emerged during the 1990s followed DiMaggio's (1988) admonition that institutional theory not neglect interest and agency with regard to institutions. Using the idea of "institutional entrepreneurship," DiMaggio recognized the possibility that organizations could shape and change institutions. Christine Oliver (1991) followed with on influential piece describing potential responses to institutional pressures, beyond passive acquiescence. Most recently, Lawrence and Suddaby (2006) describe "institutional work" in which people and organizations create, maintain, and disrupt institutions as they act on their interests.

Methodologically, institutional researchers exploited the theory's capacity to map across levels of analysis and to include technical, cultural, historical, and symbolic elements in a range of indus- 
tries, across many types of business and organizational phenomena traditionally in the strategy domain. For example, Leblibici, Salancik, Copay, and King (1991) showed how players on the periphery changed the shape of the radio industry by creating innovations that were taken up by the core companies in the field. Rao (1994) described how companies in the automobile industry created and used contests and racing as mechanisms to acquire legitimacy in the new field otherwise without clear markers of acceptance. To understand the persuasive strategies used by the (then) Big Five accounting firms to establish the legitimacy of product diversification outside the field of accounting, Suddaby and Greenwood (2005) employed rhetorical analysis. Greenwood and colleagues (2008: 31) describe the transition that occurred in the research program of institutional theory (italics in original):

Perhaps the most notable shift in emphasis and interpretation over the past three decades has been from treating the context of social values and ideas as influences upon organizations, towards recognition of the interplay of organizations with their contexts.

While still focusing on social arrangements that constitute organizational life, institutional theory began to explore how these arrangements are effected by people and organizations. The theoretical and methodological robustness of institutional theory-its capacity to capture the conditions of stability and change-has been reflected in the growing influence of institutional theory in the study of organizations. In survey research, scholars in the field have rated institutionalism in organizational analysis as one of the most important theories of organization (Miner, 2003). Institutional theory has been described as the dominant perspective in organization theory (Davis \& Marquis, 2006; Miner, 2002; Mizruchi \& Fein, 1999; Walsh, Meyer, \& Schoonhoven, 2006), but, more important, the robustness of institutional theory for capturing the complexity of both stability (enabling and constraining action) and change has led to greater commonality of interest between institutional and strategy research. In the next section, we more formally discuss this ropprochement.

\section{The Integration of Institutional Theory Into Strategic Management Research}

Institutional theory has become increasingly relevant to strategy-for reasons involving both the business context of practice and a growing body of research that Ingram and Silverman (2002) argue has reached critical mass. They note that strategic management scholars have always understood the importance of institutions, but saw them as "givens" in the business environment, and not worthy of research. They add, however, that key factors, such as the decline of socialism, the globalization of business, and technological change have put the institutional environment in which business takes place front and center as a key business concern. Perhaps the most dramatic statement of the relevance of institutional theory to management practice came from Warren Buffet in the 1989 letter to Berkshire Hathaway shareholders. $\mathrm{He}$ said,

My most surprising discovery: the overwhelming importance in business of an unseen force that we might call "the institutional imperative." In business school, I was given no hint of the imperative's existence and I did not intuitively understand it when I entered the business world. I thought then that decent, intelligent, and experienced managers would automatically make rational business decisions. But I learned over time that isn't so. Instead, rationality frequently wilts when the institutional imperative comes into play (Chairman's Letter, Berkshire Hathaway, 1989. http://www.berkshirehathaway. com/letters/1989.html, accessed September 5, 2009).

These practical issues have shown up in the strategy research agenda. The advantages of global strategies are often contingent on cultural and relational constraints and the stability of institutions for enabling and regularizing transactions (Aguilera \& Jackson, 2003; Hoskisson, Eden, Lau, \& Wright, 2000; see also Kostova, Roth, \& Dacin, 2008, for a review of the growing research on multinational corporate strategy that uses an institutional lens). Technological developments must diffuse through more or less highly networked and institutionalized environments, so the strategies adopted to establish new, advantageous standards (Garud, Jain, \& Kumaraswamy, 2002) or to increase the acceptance of an innovation by the public (Hargadon \& Douglas, 2001) are critical to success. Institutional theory also has become more central to entrepreneurship research, focusing on institutional entrepreneurship-purposive actions to create or change institutions to facilitate new practices beneficial to particular individuals and organizations (Ireland \& Webb, 2007). 
To specify the volume of recent research integrating institutional theory into strategy, we identified studies published from 2000 to 2008 that employ institutional perspectives to understand topics within the strategy domain, which appeared in leading management journals (Administrative Science Quarterly, Academy of Management Review, Academy of Management Journal, and Strategic Management Journal). ${ }^{1}$ The year 2000 starting point is the last year covered in the bibliometric studies of strategy, and it covers the period marking the rise of the institution-based view in strategy (Peng, Sun, Pinkham, \& Chen, 2009).

Perhaps the most compelling evidence of the growing integration of institutional theory to strategy is the 13 articles we found using an institutional theory lens that have appeared in the Strategic Management Journal since 2000. For example, several studies were published examining the effects of country-based political and economic institutions on strategic decisions and performance outcomes (cf. Crossland \& Hambrick, 2007; Delios \& Henisz, 2003; Kriauciunas \& Kale, 2006; Luo, 2002). Other studies focused on the importance of legitimacy to the effectiveness of strategic decisions (cf. Dacin, Oliver, \& Roy, 2007; Lounsbury \& Glynn, 2001). The other major journals in management also clearly mark the marriage of institutional theory and strategy, with a total of 42 articles published that employ institutional theory to examine traditional strategic topics such as governance; entry strategies; strategy implementation; stock price performance; alliances; corporate entrepreneurship; diversification; and pricing.

What is clear from this interpenetration of strategy and institutional research is that institutional theory enacted in the current literature has gone beyond construction of actors as "cultural dopes" (Hirsch \& Lounsbury, 1997). Instead, those engaged in "institutional work," are "culturally competent actors with strong practical skills and sensibility who creatively navigate within their organizational fields" (Lawrence \& Suddaby, 2006: 219). This brief overview of the histories of institutional theory and strategy lends support for the choice to examine the integration of institutional theory into strategic management textbooks. The two fields began and developed in parallel, but their interests have converged. A field that was anathema to strategic management changed in focus while the strategic management discipline was coming to grips with new realities in a business environment

\footnotetext{
${ }^{1}$ The articles identified in this search are indicated with an asterisk at the beginning of the citation in the reference list.
}

where institutions are more obviously pervasive and consequential. This combination of factors makes the strategic management textbook an ideal venue for examining the introduction of new research and for answering our research question-to what extent is new research integrated into textbooks, particularly when the parent fields were once seen as paradigmatically distinct?

\section{METHODS}

The process of determining the sampling strategy for examining textbooks confronts a number of issues unique to the textbook market. First, sales numbers are difficult to acquire. Publishers we contacted directly for this information considered sales data to be competitive information. This has been noted in other major studies of textbooks (Lynch \& Bogen, 1997). Second, the fluctuation in sales of older editions because of textbook resales by students can also make the data difficult to interpret. For these reasons, we chose to look at adoptions- $a$ metric that is not affected by school or class size or resale processes. We used the Faculty Center Network (FCN; www.focultycenter.net), a clearinghouse of information for faculty on textbook adoptions maintained by MBS Textbook Exchange, a textbook wholesaler.

Data available as of April 2008 were used to identify the most widely adopted textbooks. We limited our search to textbooks with copyright dates of 2005 and later and used the keywords "strategic management" and "strategy" to search the database. We identified 227 titles through this search. Because the FCN methodology is based on the International Standard Book Number for individual texts, some textbooks appeared multiple times on the list because they had multiple versions on the market (e.g., with and without cases, two editions available with 2005 and later copyrights; hardcover and paperback). Removing these duplications yielded 126 titles. Faculty Center Network rates the demand for textbooks using a zero to five scale, with a score of five indicating the most popular texts. We identified books with a rating of three or higher on the demand scale, focusing on the textbooks with moderate or higher popularity. By taking this strategy, we were able to identify texts adopted by a range of schools. We excluded from the sample textbooks in which the title indicated a focus other than strategic management (e.g., "advertising strategy" or "public relations strategy"). In all cases we used the most current version for our review. From this process we identified 18 textbooks (Appendix).

This sampling process compares favorably to 
the sampling strategy in previous studies of textbook content that have appeared in major journals. For their Administrative Science Quarterly study on differences between texts in two disciplines, Levitt and Nass (1989) used a snowballing technique among editors to get their estimation of bestselling textbooks. Similarly, in their American Sociological Review piece on sociology texts, Lynch and Bogen (1997) contacted several publishers to have them name the most popular introductory sociology texts. Rather than using publishers as an information source, we used data collected from adoptions logged at more than 3,000 booksellers listed on the FCN website. In both previous studies, the authors limited their study to the top-10 texts. Lynch and Bogen (1997) quote a publisher who indicated that $80 \%$ of sales were attributable to the top-10 books in sociology. Our sample of 18 books in strategic management compares favorably to these prior studies.

To determine whether institutional research has penetrated the texts, we created a comprehensive list of authors, articles, and key terms from institutional theory. We created the list of authors and articles from two primary sources. First, we used the published work in the major journals from 2000-2008, in which an institutional lens was used to study strategic issues. Next, we culled institutional works, authors, and citations from the references of the introductory chapter to the Sage Handbook of Organizational Institutionalism (Greenwood et al., 2008). We created both a "name" list of institutional scholars and an "article" list of institutional works. For the scholars list, we asked an institutional scholar who has co-edited two books in the institutional field to verify that scholars on the list were institutional scholars. From these sources, we had a list of 75 names and 123 articles. We also included key institutional terms, including all forms of the words institution, legitimacy, logic, and isomorphism to complete our comprehensive list. ${ }^{2}$

The next step in the process was to review the index of each textbook for each of the names, articles, and terms to identify sections that might include institutional research. We recorded the page number for each and then located the referenced section. During this process we found that a citation of a work or an author did not necessarily indicate integration of institutional concepts to strategy text content. Therefore, our next step was to review each referenced section to verify whether

\footnotetext{
${ }^{2}$ The list of terms, names, and articles is available from the authors.
}

the text used institutional content. Using Scott's definition of institutions (see above) as the referent, two coders read the text to assure that it referenced institutional processes. They reached agreement most of the time, with a Cohen's Kappa (Cohen, 1960) of .95, indicating very high interrater reliability (Landis \& Koch, 1977). The coders subsequently reconciled the disagreed-upon sections.

An example of a citation that was on our list of institutional articles that was not used to reference institutional content is in Thompson, Stricklond, and Gamble (2008). For the following passage, they cite Zbaracki's (1998) study of institutional processes in TQM adoption:

Total quality management (TQM) is a philosophy of managing a set of business practices that emphasizes continuous improvement in all phases of operations, 100 percent accuracy in performing tasks, involvement and empowerment of employees at all levels, team-based work design, benchmarking and total customer satisfaction (Thompson, Strickland, \& Gamble, 2008: 396).

Although the Zbaracki study clearly concerns institutional processes, it is the definition of TQM Zbaracki uses that is being cited rather than the institutional content of his study, so we did not count it as an institutional reference.

After identifying the sections of the textbooks with institutional content, we expanded the quantitative assessment of integration by considering the amount and prominence of the penetration. We determined the number of pages in the text that addressed institutional theory by counting the number of lines for each section and then dividing the number of lines by the average number of lines per page in the textbook. We next counted how many times the keywords appeared in the text and whether these keywords appeared in chapter headings or subheadings. We suggest that the page count of text, the count of keywords, and the number of times a keyword appeared in a heading represent an increasing hierarchy of integration. When a keyword appears in a heading, it can be argued to be a part of the primary topical outline of the textbook.

To provide a baseline of comparison for the integration of institutional theory, we also investigated the extent to which agency theory research had penetrated the strategy textbook. We selected agency theory because it emerged at approximately the same time as institutional theory (e.g., Jensen \& Meckling, 1976, and Fama \& Jensen, 1983, for the former and Meyer \& Rowan, 1977, and 
DiMaggio \& Powell, 1983, for the latter), and the seminal scholars for both theories are considered outside the strategic management domain. However, agency theory, which addresses problems that arise when the goals and risk preferences of principals and agents are misaligned, was more quickly embraced by strategic management scholars because such economic theories added to the legitimacy of the field (Hambrick \& Chen, 2008), and the theory was consistent with the economic view of strategy. The names and works of the seminal authors (Foma, Jensen, Meckling) were identified in the bibliometric studies of strategy research (Nerur et al., 2008; Ramos-Rodríguez \& RuízNavarro, 2004) and "agency" is considered part of the distinctive lexicon of strategic management (Nag et al., 2007). We added these seminal scholars' names and the key words "agent/agency" and "principal" to our search process. By taking this approach, our results for agency theory's integration provide a control of sorts through which we can compare coverage of topics that emerged in the literature at approximately the same time, but that represent different paradigmatic genealogy.

\section{RESULTS}

Our analysis indicates that authors with multiple titles did not vary in the extent to which they integrated institutional theory into their textbooks, often using the same citations across versions. To avoid appearing to overstate our results, we show the results for only a single title by each group of authors in Table 1, which includes 14 textbooks. Of the 14 titles, 7 had at least some institutional content. In comparison, 12 of the 14 had agency content. Besanko, Dranove, Shanley, and Schaefer (2007) had by far the greatest amount of institutional content, having twice the percentage of pages and six times the keyword usage when compared to its nearest competitors (Ghemawat, 2006, and Hitt et al., 2009, respectively). Furthermore, only Besanko et al. (2007) used an institutional keyword in a section heading (three occurrences). The means in Table 1 are heavily skewed by Besanko et al. Removing Besanko et al. from the sample brings coverage of institutional theory to just over $10 \%$ of the coverage that agency theory receives (.23 versus 2.13 pages and 1.84 versus 14.76 key-

TABLE 1

Institutional Coverage in Strategic Management Texts

\begin{tabular}{|c|c|c|c|c|c|c|c|c|c|}
\hline Text & $\begin{array}{l}\text { Number of } \\
\text { References } \\
\text { Evaluated }\end{array}$ & $\begin{array}{c}\text { Number of } \\
\text { References } \\
\text { With } \\
\text { Institutional } \\
\text { Content }\end{array}$ & $\begin{array}{l}\text { Percent } \\
\text { Citations }\end{array}$ & $\begin{array}{c}\text { Pages of } \\
\text { Text }\end{array}$ & $\begin{array}{c}\text { Percent } \\
\text { Pages }\end{array}$ & $\begin{array}{c}\text { Key Word } \\
\text { Counts }\end{array}$ & Titles & $\begin{array}{l}\text { Pages in } \\
\text { Book }^{\alpha}\end{array}$ & $\begin{array}{c}\text { Foot/End } \\
\text { notes }\end{array}$ \\
\hline Barney \& Hesterley & 6 & 0 & 0 & $0(1.7)$ & $0(.5)$ & $0(9)$ & $0(1)$ & 293 & 331 \\
\hline Baye & 1 & 0 & 0 & $0(8)$ & $0(1.9)$ & $0(8)$ & $0(3)$ & 419 & 239 \\
\hline Carpenter \& Sanders & 12 & 1 & .2 & $0.2(0.7)$ & $.04(.14)$ & $3(16)$ & $0(0)$ & 431 & 490 \\
\hline David & 3 & 0 & 0 & $0(0)$ & $0(0)$ & $0(0)$ & $0(0)$ & 236 & 203 \\
\hline $\begin{array}{l}\text { Dess, Lumpkin \& } \\
\text { Eisner }\end{array}$ & 12 & 0 & 0 & $0(1.2)$ & $0(.3)$ & $0(37)$ & $0(2)$ & 355 & 800 \\
\hline Ghemawat & 2 & 2 & .8 & $.4(.3)$ & $.26(.22)$ & $3(3)$ & $0(0)$ & 143 & 257 \\
\hline Grant & 9 & 2 & 3 & $.3(1.6)$ & $.08(.45)$ & $7(8)$ & $0(0)$ & 358 & 681 \\
\hline Pearce \& Robinson & 0 & 0 & 0 & $0(3.5)$ & $0(1.0)$ & $0(12)$ & $0(4)$ & 339 & 132 \\
\hline $\begin{array}{l}\text { Thompson, Gamble, } \\
\text { \& Strickland }\end{array}$ & 1 & 0 & 0 & $0(0)$ & $0(0)$ & $0(0)$ & $0(0)$ & 409 & 373 \\
\hline Walker & 17 & 3 & 1.0 & $.6(1.3)$ & $.25(.56)$ & $3(5)$ & $0(1)$ & 240 & 307 \\
\hline$M$ & 10.36 & 2.00 & .32 & $.54(3.97)$ & $.15(.81)$ & $5.14(18.64)$ & $.21(.80)$ & 331.21 & 556.07 \\
\hline $\mathrm{S} D$ & 13.66 & 3.46 & .44 & $1.20(7.04)$ & $.28(1.71)$ & $12.63(22.62)$ & $1.09(1.92)$ & 87.52 & 457.52 \\
\hline
\end{tabular}

Note: (Agency comparisons in parentheses.)

${ }^{\alpha}$ Page counts exclude front matter, cases, glossaries, appendices, indexes, list of notes, and end of chapter review material/ exercises.

b These authorship teams had two or three (for Hill \& Jones) different titles in the sample. Though the books were unique and not just earlier versions of the same textbook, the amount of institutional coverage was identical for books written by an authorship team. For parsimony the table includes only one representative book for each authorship team. 
words for institutional and agency theory, respectively). Ghemawat (2006) was notable in that it was the only book covering both theories that had more institutional content than agency theory content, although in both cases it was less than one-half page.

The most straightforward answer to our research question, therefore, is that only half the books have integrated institutional theory and research. For those books with integration the level of coverage averages about a half page, just over a page if Besanko et al. and its 4.5 pages are added to the sample. A quantitative approach, however, is a somewhat crude tool when dealing with issues of meaning, which is essential when we view textbooks as cultural artifacts. To capture a more nuanced understanding of the institutional coverage, we added a more qualitative, interpretive approach, which we describe in the following section.

\section{QUALITATIVE ANALYSIS}

Kuhn (1970) asserted that when new paradigms are introduced into textbooks, they are often presented as a natural progression of normal science. More recent studies of scientific knowledge from the interactionist perspective emphasize the very social nature of science and the idea that scientific communities are "local"-they have very different pragmatic structures that are situated in the social and cultural milieu of their disciplines. These pragmatic structures include accounts of what constitutes legitimate knowledge as well as "topical contextures" and "structures of justification" that affect how knowledge moves across contexts and communities (Shapin, 1995: 306). Institutional theory and strategy may represent two very distinctive scientific communities. At a fundamental level, strategic management is grounded in microeconomics and behaviorism, compared to institutional theory's less atomistic, more social view (Schneiberg \& Clemens, 2006). Although the wellestablished integration of institutional perspectives in strategy research led us to look for evidence of integration, the idea that textbooks are cultural productions, reflecting the discourse of a disciplinary pedagogy, would imply that incorporating institutional theory, with its significantly different paradigmatic perspective, might be problematic-if not for authors, then for publishers and adopters. In our more qualitative analysis we explore the depth of coverage by unpacking the fundamental elements of institutional theory embedded in each passage that we coded as institutional and by identifying passages that represent formal statements of institutional theory's premises. We then analyze the ways in which institutional theory is used in each text.

\section{Depth of Coverage}

Depth of coverage is important because research on student retention and learning shows that more complete or "gestalt" descriptions of concepts or theories can improve recall of conceptual information, reduce the extent of simple memorization, and improve students' ability to use theories creatively in a range of contexts (Mayer, 1989: 43). To determine the depth of coverage of institutional theory we adapted Scott's (2007: 406) definition of institutions to create three categories of coverage. First, we coded each passage for coverage about the role of institutions as social structures providing "authoritative guidelines for social behavior." Second, we coded passages for references to the content of institutions, including social structures such as "schemas, rules, norms, and routines." Finally, we determined whether passages described institutional processes through which these enduring social structures "come to be created, diffused, changed and disrupted over space and time." A single passage could reflect one of these elements or all of them.

Of the seven textbooks with institutional coverage, four included single passages containing all three elements of Scott's description of institutional theory, such that it is clear from the passage that institutions give order to social life, include some combination of rules, routines, norms, and schemas, and are both a cause and an effect of social processes. From the Besanko et al. text, we coded the excerpt describing institutional theory by parsing out segments of the definition:

Sociologists study these aspects of firm behavior by focusing on institutions, which are relatively stable organizational arrangements, often possessing a distinct identity within the broader social context, that help bring order to sets of economic transactions. Institutions can involve the formal regulation of firms, whether by government agencies or other nongovernmental regulatory organizations. They can also be less formal and involve ongoing power-dependence relationships between firms that come to be taken for granted. Finally, similar to how we discussed a firm's culture earlier in this chapter, institutional arrangements may embody general patterns of values, beliefs, and behavioral norms that motivate and stabilize affected firms (557). 
The three textbooks that did not have a single passage covering all three elements focus on only one or two components of the definition. An example of such a passage appears in Walker (2007):

A second entry path involves large-scale investments, such as telecommunications infrastructure, energy plants, or exploration facilities. In this case, especially if the investment is made in a country whose political and economic institutions are developing, there may by substantial political risk (230).

These results show that depth with regard to coverage of the basic elements of institutionalism is another source of variability among texts.

Another aspect of depth of coverage concerns the level of abstraction in coverage. Abstraction is an important vehicle through which knowledge moves from the local and specific to broader and more general domains of potential application (Cope \& Prosser, 2005). We examined the extent to which a formal statement of institutional theory was presented in the text, specifically looking for abstract descriptions of the theory such that it could easily be used for analysis in a range of contexts. Only two of the textbooks provided a full abstract definition of institutional theory-the Besanko et al. (2007; see the passage above) and Carpenter and Sanders (2009) texts. The Grant (2008) text provided a partial abstract definition, but focused only on isomorphism:

Institutional sociologists emphasize the propensity of firms to imitate one another to gain legitimacy. The process of institutional isomorphism locks organizations into common structures and strategies that make it difficult for them to adjust to change. External pressures for conformity arise from governments, investment analysts, banks, and other sources of resources and legitimacy, but also through voluntary imitation-risk aversion encourages companies to adopt similar strategies and structures to their peers (276).

It is worth noting that as our analysis has moved from the more coarse method of counts of citations, to measurement by percent of coverage by line count and by headings to an assessment of depth of coverage, we again see considerable variability between texts incorporating institutional content. We further explore the variability between texts by examining differences in how institutional theory is used in the texts.

\section{Modes of Use}

Two treatments of institutional processes consistent with the strategy consensus are prominent. The first is integration of an internal view of institutionalization in which leaders influence the institutionalization of particular practices and values within organizations. This focus is consistent with the work of Selznick (1957), developed in his influential Leadership in Administration. ${ }^{3}$ Although social in its focus, its generating imperative is the actions of managers designed to create processes that are imbued with value and that are distinctive to members of the organization. This incorporation of institutional concepts is consistent with strategy's focus on managerial action. In Carpenter and Sanders (2009), for example, the authors provide an abstract treatment covering all major elements of Scott's definition, but focus only on institutional processes within the organization:

The term institutionalization is widely used in social theory to denote the process of making something (for example a concept, a social role, particular values and norms, or modes of behavior) become embedded within an organization as an established custom or norm within that system. In essence, what may have been considered novel, difficult, or even revolutionary at the beginning of the change process now becomes almost taken for granted, and new hires to the organization will often assume that the firm always operated that way (428).

The second major use of institutional theory appears in chapters and sections dealing with globalization and international strategy or the political and legal context. These discussions tend to focus on nation-based variability in cultures and practices as well as political and legal institutions that facilitate or impede action. As with on organization's internal culture, these factors are described as variables that affect managerial discretion or introduce risk, but are knowable as part of competitive analysis and are actionable elements in strategic decision making. In the Hill and Jones (2008c) text, political and legal forces are discussed with regard to both firms and industries:

In most countries, the interplay between political and legal forces, on the one hand, and

\footnotetext{
${ }^{3}$ An upcoming Academy of Management Review special issue is about the renewed focus on institutional processes in organizations (Suddaby, Elsbach, Greenwood, Meyer, \& Zilber, 2007).
} 
industry competitive structure, on the other, is a two-way process in which the government sets regulations that influence competitive structure, and firms in an industry often seek to influence the regulations that governments enact by a number of means (70).

Consistent with the treatment of institutions as external to the manager, the Ghemawat (2006) book discusses the importance of analyzing competitors' routines as part of the competitive analysis process. Although Ghemawat (2006) fully describes institutional processes, he maintains strategy's manager-centered focus. Pointing out that such an analysis is essential and different from the economic and technical analyses of $a$ competitor's position, Ghemawat (2006: 80) argues that a competitor's behaviors "may not be entirely purposeful," and are easily anticipated by traditional strategic analysis.

The juxtaposition of the discussions of internal institutional processes with the view that institutions are part of the external environment in some texts reveals an interesting paradox. The actions of organizations to create a distinctive identity and particular values are deliberate. When analyzing the behaviors of other organizations and their routines, the routines are not "entirely purposeful," or institutions are part of the external political or regional fabric. These are variables for managers to consider. This paradox is not necessarily inappropriate, given the consensus definition of strategy that puts the manager at the center of actions designed to create advantage for the firm. From the perspective of the manager, both the organization and its environment are variables to be understood and affected. This is a prescriptive perspective in the textbooks that does not include the aspect of institutional theory that also casts managers as embedded in taken-for-granted social arrangements.

Two of the texts directly take a less paradigmatically consistent approach to describing institutional processes. Grant (2008) describes isomorphic processes as a factor inhibiting change and social legitimacy as an imperative separate from technology in determining survival. ${ }^{4}$ Ironically, the textbook listed in the FCN database under managerial economics and microeconomics subjects as well as business strategy, Besanko, Dranove, Shanley, and Schaefer (2007), is the only textbook

\footnotetext{
${ }^{4}$ In the latter, Grant actually describes an ecological process, but the idea of social legitimacy is used in its institutional sense.
}

of this sample that dedicated an entire chapter to issues of environment, power, and culture, much of which engages institutional theory, fully describing processes, terms, and implications for strategic management. Just as the divergence from the consensus view of strategy may be a reason that there is variability in coverage across strategy textbooks, the textbook that might be best described as outside the management-based consensus on strategy appears to be the only one substantially integrating institutional perspectives.

What is notable about the Besanko et al. (2007) text is the extent to which the discussion of the environment directly engages institutional research, not as a footnote, but as an integrated part of the discussion and as essential to understanding the phenomena described. For example, the textbook dedicates an entire page to the Davis and Thompson (1994) study on governance, describing its theoretical framing, its results, and its implications, then follows the description of the study with contemporary examples. The topic of institutional logics has its own section with Thornton and Ocasio's (1999) study on the change in logic in the higher education publishing industry, as well as describing in detail Haveman and Rao's (1997) study of the evolution of the thrift industry in California. The textbook treatment of the thrift industry study includes the following description of the development of institutional logics for these precursors of savings and loan firms:

They found that these institutions developed in part as a result of experimentation and technical problem solving. They also developed under the influence of more macro pressures of large population growth and the development of values of bureaucracy and voluntary effort associated with Progressivism, in opposition to the less formal and more collective values characterizing early thrift plans (Besanko et al., 2007: 562-563).

Rather than using a narrative with the manager's perspective as the focus, a researcher's perspective is adopted, which places the manager "in" the narrative, as much a part of the plot as the author of it.

This analysis demonstrates that decisions about the pedagogical narrative and its structure can have an impact not just on what or how much research is brought into textbooks, but how it is introduced. The results of our initial analysis on coverage of institutional themes indicate that although institutional theory has become importont in the research literature, its inclusion in 
many textbooks lags behind the research. Our qualitative analysis suggests the very narrative structure of the textbook may have something to do with how new research is introduced. If textbooks are written to provide prescriptive methods for making and executing strategy, some aspects of institutionalism may not fit easily. In the following section, we explore these ideas more fully, discuss some limitations of this study, and suggest an agenda for future research.

\section{DISCUSSION}

Textbooks are a central, yet under-researched, aspect of business education. Recent calls to attend to the textbook as a conduit for bringing academic research to practice recognize the textbook's centrality (Rousseau, 2006; Rousseau \& McCarthy, 2007), but may underestimate the complexity-and the sociality - of the textbook as itself a highly institutionalized artifact. In this study we set out to examine the extent to which on increasingly important stream in the scholarship of organizations and strategy has been introduced into strategic management textbooks. Motivated by theory in the sociology of scientific knowledge suggesting that determination of what is legitimate knowledge and codification of that knowledge in textbooks is a social process (Kuhn, 1970), we chose institutional theory in the strategic management text as a focal case. Although we found several texts included citations from studies with institutional content, in only two were less manager-centric perspectives taken, and in only one was significant attention paid to the theory itself and its implications to strategy beyond simple utility for managers. Several texts had no institutional citations at all. This variability suggests that the movement of research to the textbook may be a considerably more complex issue than anticipated in previous commentary.

Knowledge defined in textbooks is a cultural production connecting multiple communities and interests-practitioners, current and former students, teachers who are researchers and teachers who are not, accrediting associations, assessment committees, faculty in other disciplines, authors of texts, and publishers - to a common artifact. When seen from this perspective the processes associated with deciding what goes into textbooks and what should be removed is a much more social and cultural process than common views of the text as a means for mechanical transfer of research to practice would suggest (Rousseau, 2006; Rousseau \& McCarthy, 2007). Based on our results, and linking our findings to the literature on the sociology of scientific knowledge, discourse, and institutional theory, we discuss some of these issues in the following sections. We first focus on the textbooks in this study as texts revealing a relatively common discourse of strategic management pedagogy. We then describe institutional processes in higher education publishing that also may affect content choices. Finally, we explore the possibility that textbook content is a function of author preference and experience and we also explore the implications of that possibility.

\section{The Discourse of Strategic Management Pedagogy}

Although we found either no or limited coverage of institutional theory in most texts in the sample, our qualitative analysis revealed that in most cases when institutionalism is brought into textbooks, the usage downplays the fundamentally social and intersubjective nature of institutions and puts the manager "outside" of institutions. Institutions and institutional contexts are variables for consideration in strategic decisions or in the creation of distinctive organizational values. This trope connects institutional phenomena to the thematically consistent view of strategy and its managercentric lens. Managerial action is depicted as rational (or boundedly so), and the purpose of action is competitive advantage- $\alpha$ view consistent with microeconomic assumptions. Although institutional theory has embraced individual and organizational agency, the actors in institutional research are nonetheless embedded in social arrangements. Further, institutional processes are often indeterminate, (Bohman, 1993), making them a poor fit for a normative narrative structure used in many textbooks.

These issues suggest that integrating institutional theory poses significant challenges to existing discourse in textbooks. Discourse is a way of talking about an object or idea that constructs its meaning; discourse "rules in" certain concepts and "rules out" others (Phillips, Lawrence, \& Hordy, 2004: 637). Texts (writ broadly) are the vehicle through which discourses can be studied and understood (Fairclough, 1995), and, in this case, the textbook can be understood to uncover a relatively clear discourse of strategy pedagogy. Even as institutionalism is understood to be relevant to academic research in the field of strategy, it is not easily brought into strategy pedagogy. Following Phillips, Lawrence, and Hardy (2004), the minimal role of institutional theory in texts, and the more generally manager-centric, behaviorist and microeconomic bases of most books in this sample, may 
be evidence that the pedagogy and its discourse is institutionalized. If so, the introduction of a more clearly social, historic, and cultural framework may be "ruled out," and treatments of the theory more in keeping with a behaviorist or microeconomic approach "ruled in."

Although internal coherence may be a desirable goal within a textbook, coherence also is particularly important when the discourse is widely shared across situations and is stable over time (Phillips et al., 2004), which is the case with the widely dispersed market for strategy textbooks. It is important to look at mechanisms through which this stability occurs. Publishers play an important role in shaping the pedagogical narrative by mediating multiple interests in the textbook morket. In the following section, we describe the institutional processes in the textbook market that may affect content.

\section{Institutional Processes in Textbook Publishing}

In a study of sociology and physics textbooks in the publishing industry, Levitt and Nass (1989) demonstrated that institutional forces for homogeneity profoundly influenced decision making in the industry. Texts that are developed based on a particular pedagogical narrative are replicated in such a way that the content, sequencing, and perspectives established in those early versions become "infused with value" (Selznick, 1957) among adopters such that early constructions become taken for granted as correct and meaningful (Ballentine, 1988; Norgaard, 1981).

There is reason to believe the preferences of adopters have a great deal of influence on the publication process in recent years. Although textbook publishing has long been a for-profit enterprise, shifts in the configuration of the industry have led to profound changes in the logic that underlies the publication process (Powell, 1980; Thornton \& Ocasio, 1999). Higher education publishing moved from an editorial logic, in which the editor-author relationship held sway, and sales and reputation were the outcomes of interest, to a market logic, in which profit and market position are critical. The author-editor as determinant of content has given way to heightened receptiveness to preferences of adopters (Thornton \& Ocasio, 1999). Best-selling author Stephen Robbins would seem to confirm the new relationship between author and publisher (in Cameron et al., 2003: 716):

Publishers are in the business of selling books. They'll sell anything if they think peo- ple might want it. They don't care about integrity or quality. Moreover, they firmly believe that they create books. They have little respect for authors.

Lynch and Bogen (1997: 485) confirm a conservative bias among risk-averse publishers, indicating that they "tend to work with a boilerplate model of the successful text and to make only cosmetic adjustments."

As a result of this combination of forces, content and particularistic interpretations can span generations and editions, and persist as the content of textbooks becomes disconnected from the original research and a pedagogical story is diffused and institutionalized, coming to represent a legitimate disciplinary pedagogy (Dent \& Goldberg, 1999; Goodwin, 1991; Lapakko, 1997; Paul, 1988). Not only does this shared discourse create a broad understanding of the meaning of a particular discipline, it is connected to material practices in the classroom (see Gilbert \& Mulkay, 1984; Woolgar, 1981)_ lectures, assignments, presentations, and, most recently, assessments. As instructors are increasingly privileged in the publication process, their expectations that texts are consistent with the discourse they practice become more salient.

Even agency theory, which emerged from economics, did not quickly move into textbooks. We contacted a member of the authorship teams from the three textbooks that had the greatest number of pages devoted to agency theory to determine when the theory had been incorporated. Of these three textbooks, the earliest explicit appearance of agency theory was in Hitt et al. in 1997, which introduced a chapter on corporate governance. Pearce and Robinson and Hill and Jones explicitly incorporated agency in 2000 and 2004, respectively.

\section{Particularistic Explanations-Author Preference}

Given these institutional and industry forces, how can we explain the apparent defection represented by the Besanko et al. (2007) textbook? The first possibility is that, because the book is marketed as an economics of strategy text, it falls outside the coherent pedagogy of strategic management. Although an economics-focused text seems an unlikely location for extensive exposition on institutional processes, the fact that the book does not target the same market and is not part of the highly intercalated network of interests associated with strategic management pedagogy means that innovation may be more likely. The second explanation might be found in the preface to the fourth edition, which positions the text as deliberately different: 
Most of the available texts in strategic management lacked disciplinary grounding. Few contained serious discussions of economics principles that are essential to strategy ... Moreover, most of these books were targeted at more general audiences than what one finds at a business school such as Kellogg. We learned that we were not the only ones struggling to find an appropriate text for teaching business strategy. Indeed the choice of a text for the core strategy course appeared to be problematic at many business schools (Besanko et al., 2007: vi).

Thus, they describe a niche strategy, one that is determined to separate itself from the institutionalized strategic management pedagogy. Their defection from what might be described as the dominant pedagogical discourse is deliberate and entrepreneurial.

This suggests that one reason for the more general variability between texts with regard to institutional theory might be the theoretical preferences, research experience, or bias of authors. The coverage of institutional theory (or absence of coverage) simply may be a function of the author's perspective. We conducted a literature search on the textbook authors in this study using the terms "institution" and "legitimacy" jointly with the authors' names. Some of the texts with institutional content had at least one author who had written on institutional topics, even if institutional theory was not the author's primary research stream (e.g., Fombrun \& Shanley, 1990; Hitt, Ahlstrom, Dacin, Levitas, \& Svobodina, 2004; Sanders \& Tuschke, 2007). On the other hand, some textbooks in which we found no institutional content had authors who had written on institutional topics or processes (e.g., Barney \& Hansen, 1994; Lumpkin \& Dess, 1996). As a result, we cannot show that author preference, bias, or familiarity is an easy explanation for content, but we also cannot rule it out. The extent to which author bias affects textbook content must be explored in future research, and such study is warranted. If textbook content is driven by the theoretical commitments, preferences, or biases of authors, this suggests that "evidencebased management" in textbooks is not so simple in a field characterized by such paradigmatic pluralism (Pfeffer, 1993). But we suspect the textbook authors themselves would reject the assertion that their biases drive content. In discussing his decisions about incorporating new topics in his textbooks Stephen Robbins asserts the new topics "surfaced from recent research rather than my per- sonal agenda in seeing these topics included" (in Cameron et al., 2003: 715). Nonetheless, important to note as well is that individual authors work in communities of research and teaching practice, and their preferences are produced and maintained in a social milieu. Therefore, it remains critical that textbooks are viewed as a social or cultural artifact even if author preference drives content.

\section{LIMITATIONS}

Interpretation of the results of this study should be conditioned on the method that we used. First, we chose to use institutional theory as a single case to examine penetration of new research to the textbook. This method has been used before in studies of textbooks (e.g., Lapakko, 1997; Lynch \& Bogen, 1997), and has been described as appropriate for examining the movement of knowledge from one situated context to another (Shapin, 1995). Nonetheless, examination of a range of cases, which are more or less consistent with a particular textbook pedagogy, may surface more detailed discursive mechanisms of both conformity and defection.

Second, the difficulty of obtaining archival market data or a means to assess the validity of the adoption data that we used makes it difficult to draw conclusions about all texts and "the market." Perhaps this is one reason that there has been such a paucity of research on such an obvious pedagogical method. Other researchers have noted this difficulty and have used industry informants to generate their samples. We used adoption data from a textbook warehousing firm. Which is the best approach is open to question. Industry informants tend to focus on "best-sellers" which may overrepresent very large schools and underrepresent "boutique" schools, and thus underrepresent particular texts. The most obvious deficit in this sample is that it covers only North American schools. Although the benefit is that it is a relatively coherent educational culture and market, the restricted sample means that important insights that might be obtained by looking at an international sample are lost.

Another limitation to our method is the use of citations and keywords to determine institutional content. Our list of articles and authors was extensive, representing a more systematic approach to textbook coverage analysis than has been used before, but it is possible that coverage of institutionalism is in the textbooks, and is simply not cited. Uncited work in textbooks often is an indicator of taken-for-granted status (Shapin, 1995), but this seems unlikely in the case of the strategy 
textbook. There are few concepts more taken-forgranted in strategy than the "Five Forces Model" (Porter, 1980), but Porter is cited in every text. This would appear to lend support for the citation search method, but we cannot be certain that we have captured all institutional content with this method.

We began this study with a simple research question: "To what extent does a research stream, having gained traction in the scholarly literature, move into textbooks, especially when that research stems from a different paradigm?" We found some evidence of integration, but exposed variability in treatment that suggests that research on the textbook should be expanded, accelerated, and grounded in sociological theories of science and knowledge. It also indicates that researchers and teachers-as an academic communityneed to more closely attend to the textbook and its role in business education. In the following section, we discuss some prospects for future research and propose ways that the Academy of Management and Academy of Management Learning \& Education can play a more central role in production and study of textbooks.

\section{IMPLICATIONS FOR FUTURE RESEARCH AND PRACTICE}

The first set of questions for future research would extend this study to examine other major theories to determine how tightly linked research is to textbooks. The theories should represent different paradigms and different levels of consensus with the dominant paradigm. Sample textbooks should be chosen to represent a range of markets and should include texts varying in their emphases on practicebased or theory-based approaches. The implications of variation- or lack of variation-should be fully explored. What are the consequences of an institutionalized pedagogy when research is increasingly interdisciplinary and determined to be appropriately so? Is the normative voice in some textbooks getting in the way of integrating more indeterminate theories? Are approaches to textbooks that are more theory- and research-focused more amenable to integrating new literatures? Pedagogical discourse appears to explain what gets added or left out of textbooks; does it also explain what remains in textbooks?

A second line of research should focus on the higher education textbook industry and its implications for education in general and business education in particular. The potentially negative effects of market logics on business education have been noted (Pfeffer \& Fong, 2004; Trank \& Rynes, 2003) and the tendency of the textbook market to conservatism and isomorphism may be another means through which market imperatives affect the curriculum. Research on the mechanics of textbook production would be a useful way to determine the influence of market forces on textbook content. There is evidence that publishers' market uncertainties are a mechanism through which homogeneity has emerged (Leavitt \& Nass, 1989), but the precise nature of publishing decisions is worthy of study. This research should include authors, development editors, and others who play a part in the specific decisions about content. An important part of this process would be discovery of how focus groups and market research is used, and who participates in these studies. For example, if focus groups and survey respondents tend to be faculty who are not actively engaged in research, on what basis do they judge new (and old) material? To what extent do editors and authors use this information?

Discourse analysis is another promising focus of future research. What are the underlying structures and genres used in textbooks, and what is their meaning? Writing and reading are social acts (Hintz \& Couch, 1973), so literary and rhetorical theories that explore the authorship and reading processes would be useful in understanding both persistence and change (Fish, 1980; Tompkins, 1980). How do authors rhetorically position their ideas to either support or undermine dominant views? How are successful translations to practice through the textbook and teaching made (Sutcliffe \& Wintermute, 2006)?

This study also highlights issues that might be worthy of exploration among the academic community as an implication for teaching practice. First, considerable vigilance is needed to assure that assessment does not reinforce old knowledge at the expense of new. With the institutionalization of assessment programs through AACSB and other accrediting organizations, many schools may be using textbooks as a source of information to find what is the "body of knowledge" in various disciplines. Recently, textbook publishers have begun categorizing test bank questions according to which AACSB requirement is being measured. Using assessment tests based on textbooks that institutionalize particular ideas as legitimate knowledge will "lock in" these ideas, especially if measures need to remain the same over time to measure improvement in instruction. Assessment, in other words, may be another mechanism through which ideas become entrenched at the expense of newer research and theory. To the ex- 
tent that textbooks are the primary pedagogical technology that transcends geography and time, they will be a reference for assessment. What are the implications to business education and its capacity to absorb new knowledge?

Finally, little attention is paid in the general academic research literature to teaching. We generally expect an "implications for practice" section at the end of our journal articles, but do not require an "implications for teaching" section in disciplinary research. One important commitment scholars in every field can make is to work toward moving their research to practice through teaching by building in a discussion of how the research contributes to what is taught. A second strategy to more tightly link research to teaching is to build a "teaching translations" section into Academy of Management Learning \& Education comparable to the research translations section of Perspectives. The journal would then become not only a vehicle that improves how faculty teach, but also, in a very immediate sense, what is taught. In other words, the academic research community can become active participants in the construction of the field's pedagogy. At the very least, such issues as whether institutional theory, or any other development from research, should be in textbooks might be topics of open discussion.

In posing these questions and suggesting ideas for practice, we hope to generate increased attention to the textbook as substance and symbol. Our examination of institutional theory and strategy textbooks does not necessarily represent advocacy of its integration into the strategy textbook, but, rather, the case of institutional theory and strategy is useful because of its historic and paradigmatic complications. The results suggest the study of textbooks may provide important insights into relationships between research, teaching, and practice, and may even deepen our understanding of the social and cultural relationships between our disciplines. By introducing the sociology of scientific knowledge to the study of textbooks in management, we contribute to management education and learning by challenging researchers to take a more theoretical lens to issues of transfer of research knowledge or evidence to students and practice. This theoretical perspective holds that textbooks are not simple catalogs or repositories of evidence, but rather social and political productions-cultural artifacts that reflect complex relationships between those who produce them, those who consume them, and the social environment in which they are embedded.
APPENDIX

Textbooks Reviewed for Study

\begin{tabular}{|c|c|c|}
\hline Authors & Title & Year \\
\hline Barney \& Hesterly & $\begin{array}{l}\text { Strategic Management and } \\
\text { Competitive Advantage, } 2 \mathrm{e}\end{array}$ & 2008 \\
\hline Baye & $\begin{array}{l}\text { Managerial Economics and } \\
\text { Business Strategy, } 6 \mathrm{e}\end{array}$ & 2009 \\
\hline $\begin{array}{l}\text { Besanko, Dranove, } \\
\text { Shanley, \& } \\
\text { Schaefer }\end{array}$ & Economics of Strategy, $4 \mathrm{e}$ & 2007 \\
\hline $\begin{array}{l}\text { Carpenter \& } \\
\text { Sanders }\end{array}$ & Strategic Management, 2e & 2009 \\
\hline David & Strategic Management, $12 \mathrm{e}$ & 2009 \\
\hline $\begin{array}{l}\text { Dess, Lumpkin, \& } \\
\text { Eisner }\end{array}$ & $\begin{array}{l}\text { Strategic Management: Creating } \\
\text { Competitive Advantage, } 4 \mathrm{e}\end{array}$ & 2008 \\
\hline Ghemawat & $\begin{array}{l}\text { Strategy and the Business } \\
\text { Landscape, } 2 e\end{array}$ & 2006 \\
\hline Grant & Contemporary Strategy Analysis, 6e & 2008 \\
\hline Hill \& Jones & Essentials of Strategic Management & 2008 \\
\hline Hill \& Jones & Strategic Management Theory, 8e & 2008 \\
\hline Hill \& Jones & $\begin{array}{l}\text { Strategic Management: An } \\
\text { Integrated Approach, } 8 \mathrm{e}\end{array}$ & 2008 \\
\hline $\begin{array}{l}\text { Hitt, Ireland, \& } \\
\text { Hoskisson }\end{array}$ & $\begin{array}{l}\text { Strategic Management: } \\
\text { Competitiveness and } \\
\text { Globalization, } 8 \mathrm{e}\end{array}$ & 2009 \\
\hline $\begin{array}{l}\text { Hunger \& } \\
\text { Wheelen }\end{array}$ & $\begin{array}{l}\text { Essentials of Strategic } \\
\text { Management, } 4 \mathrm{e}\end{array}$ & 2007 \\
\hline $\begin{array}{l}\text { Pearce \& } \\
\text { Robinson }\end{array}$ & $\begin{array}{l}\text { Strategic Management: } \\
\text { Formulation, Implementation and } \\
\text { Control, } 8 \mathrm{e}\end{array}$ & 2009 \\
\hline $\begin{array}{l}\text { Thompson, } \\
\text { Gamble, \& } \\
\text { Strickland }\end{array}$ & $\begin{array}{l}\text { Strategy: Winning in the } \\
\text { Marketplace, } 2 \mathrm{e}\end{array}$ & 2006 \\
\hline $\begin{array}{l}\text { Thompson, } \\
\text { Strickland, \& } \\
\text { Gamble }\end{array}$ & $\begin{array}{l}\text { Crafting and Executing Strategy: } \\
\text { The Quest for Competitive } \\
\text { Advantage, } 16 \mathrm{e}\end{array}$ & 2008 \\
\hline Walker & Modern Competitive Strategy, $2 e$ & 2007 \\
\hline $\begin{array}{l}\text { Wheelen \& } \\
\text { Hunger }\end{array}$ & $\begin{array}{l}\text { Strategic Management and } \\
\text { Business Policy, lle }\end{array}$ & 2008 \\
\hline
\end{tabular}

\section{REFERENCES}

Note. Citations preceded with an asterisk designate studies published from 2000 to 2008 that employ institutional perspectives to understand topics within the strategy domain, which appeared in leading management journals.

*Aguilera, R. V., \& Jackson, G. 2003. The cross-national diversity of corporate governance: Dimensions and determinants. Academy of Management Review, 28: 447-465.

*Ahmakjian, C. L., \& Robinson, P. 2001. Safety in numbers: Downsizing and the deinstitutionalization of permanent employment in Japan. Administrative Science Quarterly, 46: 622-657.

Apple, M. W. 2001. Textbook publishing: The political and economic influences. Theory into Practice, 28: 282-287.

*Arthur, M. M. 2003. Share price reactions to work-family initiatives: An institutional perspective. Academy of Management Journal, 46: 497-505.

Ballentine, J. 1988. Introductory teaching and texts: How did we get into this predicament. Teaching Sociology, 26: 409-412.

*Bansal, P., \& Clelland, I. 2004. Talking trash: Legitimacy, im- 
pression management, and unsystematic risk in the context of the natural environment. Academy of Management Journal, 47: 93-103.

*Barnett, M. L., \& King, A. A. 2008. Good fences make good neighbors: A longitudinal analysis of an industry selfregulatory institution. Academy of Management Journal, 51: $1150-1170$.

Barney, J. B., \& Hansen, M. H. 1994. Trustworthiness as a source of competitive advantage. Strategic Management Journal, 15: $175-190$

Barney, J., \& Hesterley, W. S. 2008. Strategic management and competitive advantage: Concept and cases (2nd ed.). Upper Saddle River, NJ: Pearson Education.

Baye, M. R. 2009. Managerial economics and business strategy (6th ed.). New York: McGraw-Hill Irwin.

Besanko, D., Dranove, D., Shanley, M., \& Schaefer, S. 2007. Economics of strategy (4th ed.). Hoboken, NJ: John Wiley \& Sons.

Bohman, J. 1993. The new philosophy of social science. Problems of indeterminacy. Cambridge, MA: MIT Press.

Cameron, K. S., Ireland, R. D., Lussier, R. N., New, J. R., \& Robbins, S. P. 2003. Management textbooks as propaganda. Journal of Management Education, 27: 711-743.

${ }^{*}$ Campbell, J. L. 2007. Why would corporations behave in socially responsible ways? An institutional theory of corporate social responsibility. Academy of Management Review, 32: 946-967.

Carpenter, M. A., \& Sanders, W. G. 2009. Strategic management (2nd ed.). Upper Saddle River, NJ: Pearson Education.

${ }^{*}$ Certo, S. T. 2003. Influencing initial public offering investors with prestige: Signaling with board structures. Academy of Management Review, 28: 432-446.

${ }^{*}$ Chan, C., Isobe, T., \& Makino, S. 2008. Which country matters? Institutional development and foreign affiliate performance. Strategic Management Journal, 29: 1179-1206.

Chen, M.-J., \& Hambrick, D. C. 1995. Speed, stealth, and selective attack: How small firms differ from large firms in competitive behavior. Academy of Management Journal, 38: 453482

Cohen, M. 1960. A coefficient of agreement for nominal scales. Educational and Psychological Measurement, 20: 37-46.

Cope, C., \& Prosser, M. 2005. Identifying didactic knowledge: An empirical study of the educationally critical aspects of learning about information systems. Higher Education, 48: 345-372.

${ }^{*}$ Crossland, C., \& Hambrick, D. C. 2007. How national systems differ in their constraints on corporate executives: A study of CEO effects in three countries. Strategic Management Journal, 28: 767-789.

${ }^{*}$ D'Aunno, T., Succi, M., \& Alexander, J. A. 2000. The role of institutional and market forces in divergent organizational change. Administrative Science Quarterly, 45: 679-703.

*Dacin, M. T., Oliver, C., \& Roy, J.-P. 2007. The legitimacy of strategic alliances: An institutional perspective. Strategic Management Journal, 28: 169-187.

David, F. R. 2009. Strategic management concepts (12th ed.). Upper Saddle River, NJ: Pearson Education.

Davis, G. F., \& Thompson, T. A. 1994. A social movement perspective on corporate control. Administrative Science Quarterly, 38: 141-173.
Davis, G. F., \& Marquis, C. 2006. Prospects for organization theory in the early twenty-first century: Institutional fields and mechanisms. Organization Science, 16: 332-343.

Deephouse, D. L. 1999. To be different, or to be the same? It's a question (and theory) of strategic balance. Strategic Management Journal, 20: 147-162.

*Delios, A., \& Henisz, W. J. 2003. Political hazards, experience, and sequential entry strategies: The international expansion of Japanese firms, 1980-1998. Strategic Management Journal, 24: 1153-1164.

*Delmas, M., \& Toffel, M. 2008. Organizational responses to environmental demands: Opening the black box. Strategic Management Journal, 29: 1027-1055.

Dent, E. B., \& Goldberg, S. G. 1999. Challenging "resistance to change." Journal of Applied Behavioral Science, 35: 25-41.

Dess, G., Lumpkin, G. T., \& Eisner, A. B. 2008. Strategic management: Creating competitive advantage (4th ed.). New York: McGraw-Hill Irwin.

DiMaggio, P. 1988. Interest and agency in institutional theory. In L. G. Zucker (Ed.), Institutional patterns and organizations: Culture and environment: 3-22. Cambridge, MA: Ballinger.

DiMaggio, P., \& Powell, W. 1983. The iron cage revisited: Institutional isomorphism and collective rationality in organizational fields. American Journal of Sociology, 48: 147-160.

${ }^{*}$ Drori, G. S., Jang, Y. S., \& Meyer, J. W. 2006. Sources of rationalized governance: Cross-national longitudinal analyses, 1985-2002. Administrative Science Quarterly, 51: 205-229.

Fairclough, N. 1995. Critical discourse analysis: The critical study of language. London: Longman Press.

Fama, E. F., \& Jensen, M. C. 1983. Separation of ownership and control. Journal of Law \& Economics, 26: 301-326.

Fish, S. 1980. Is there a text in this class? The authority of interpretive communities. Cambridge, MA: Harvard University Press.

Fombrun, C., \& Shanley, M. 1990. What's in a name? Reputation building and corporate strategy. Academy of Management Journal, 33: 233-258.

*Gardberg, N. A., \& Fombrun, C. J. 2006. Corporate citizenship: Creating intangible assets across institutional environments. Academy of Management Review, 31: 329-346.

*Garud, R., Jain, S., \& Kumaraswamy, A. 2002. Institutional entrepreneurship in the sponsorship of common technological standards: The case of Sun Microsystems and Java. Academy of Management Journal, 45: 196-215.

Ghemawat, P. 2006. Strategy and the business landscape (2nd ed.). Upper Saddle River, NJ: Pearson Education.

Gilbert, G. N., \& Mulkay, M. 1984. Opening pandora's box: $A$ sociological analysis of scientists' discourse. Cambridge: Cambridge University Press.

*Glynn, M. A., \& Abzug, R. 2002. Institutionalizing identity: Symbolic isomorphism and organizational names. Academy of Management Journal, 45: 267-280.

Goodwin, C. J. 1991. Misportraying Pavlov's apparatus. American Journal of Psychology, 104: 135-141.

Grant, R. M. 2008. Contemporary strategy analysis (6th ed.). Malden, MA: Blackwell Publishing.

Greenwood, R., Oliver, C., Sahlin, K., \& Suddaby, R. 2008. Introduction. In R. Greenwood, C. Oliver, K. Sahlin, \& R. Sud- 
daby (Eds.), The Sage handbook of organizational institutionalism: 1-46. London: Sage.

${ }^{*}$ Guler, I., Guillen, M. F., \& Macpherson, J. M. 2002. Global competition, institutions, and the diffusion of organizational practices: The international spread of ISO 9000 quality certificates. Administrative Science Quarterly, 47: 207-232.

Hambrick, D. C., \& Chen, M.-J. 2008. New academic fields as admittance-seeking social movements: The case of strategic management. Academy of Management Review, 33: $32-54$.

${ }^{*}$ Hargadon, A. B., \& Douglas, Y. 2001. When innovations meet institutions: Edison and the design of the electric light. Administrative Science Quarterly, 46: 476-501.

Haveman, H., \& Rao, H. 1997. Structuring a theory of moral sentiments: Institutional and organizational coevolution in the early thrift industry. American Journal of Sociology, 102: $1606-1651$.

*Henisz, W. J., \& Delios, A. 2001. Uncertainty, imitation, and plant location: Japanese multinational corporations, 1990-1996. Administrative Science Quarterly, 46: 443-477.

Hill, C. W. L., \& Jones, G. R. 2004 Strategic management: An integrated approach (6th ed). Boston: Houghton Mifflin Harcourt.

Hill, C. W. L., \& Jones, G. R. 2008a. Essentials of strategic management. Boston: Houghton Mifflin.

Hill, C. W. L., \& Jones, G. R. 2008b. Strategic management theory (8th ed). Boston: Houghton Mifflin.

Hill, C. W. L., \& Jones, G. R. 2008c. Strategic management: An integrated approach (8th ed). Boston: Houghton Mifflin.

Hintz, R. A., \& Couch, C. J. 1973. Writing and reading as social activities. Sociological Quarterly, 14: 481-495.

Hirsch, P. M., \& Lounsbury, M. 1997. Ending the family quarrel: Toward a reconciliation of "old" and "new" institutionalisms. The American Behavioral Scientist, 40: 406-418.

Hitt, M. A., Ahlstrom, D., Dacin, M. T., Levitas, E., \& Svobodina, L. 2004. The institutional effects on strategic alliance partner selection in transition economies: China vs. Russia. Organization Science, 15: 173-185.

Hitt, M. A., Ireland, R. D., \& Hoskisson, R. E. 2007. Strategic management concepts: Competitiveness and globalization (2nd ed.). St. Paul, MN: West Publishing.

Hitt, M. A., Ireland, R. D., \& Hoskisson, R. E. 2009. Strategic management concepts: Competitiveness and globalization (8th ed.). Mason, OH: South-Western Cengage Learning.

Hoskisson, R. E., Hitt, M. A., Wan, W. P., \& Yiu, D. 1999. Theory and research in strategic management: Swings of a pendulum. Journal of Management, 25: 417-456.

${ }^{\star}$ Hoskisson, R. E., Eden, L., Lau, C. M., \& Wright, K. 2000. Strategy in emerging economies. Academy of Management Journal, 43: $240-267$.

Hunger, J. D., \& Wheelen, T. L. 2007. Essentials of strategic management (4th ed.). Upper Saddle River, NJ: Pearson Education.

Ingram, P., \& Silverman, B. 2002. Introduction: The new institutionalism in strategy. In P. Ingram \& B. Silverman (Eds.) Advances in strategic management, Vol. 19: 1-32. Stamford, CT: JAI Press.

Ireland, R. D., \& Webb, J. W. 2007. A cross-disciplinary explora- tion of entrepreneurship research. Journal of Management, 33: 891-927.

*Jarzabkowski, P. 2008. Shaping strategy as a structuration process. Academy of Management Journal, 51: 621-650.

Jensen, M. C., \& Meckling, W. H. 1976. Theory of the firm: Managerial behavior, agency costs, and ownership structure. Journal of Financial Economics, 3(4): 305-360.

*Jiatao, L., Jing Yu, Y., \& Yue, D. R. 2007. Identity, community, and audience: How wholly owned foreign subsidiaries gain legitimacy in China. Academy of Management Journal, 50: 175-190.

*Julian, S., Ofori-Dankwa, J., \& Justis, R. 2008. Understanding strategic responses to interest group pressures. Strategic Management Journal, 29: 963-984.

${ }^{*}$ Kostova, T., \& Roth, K. 2002. Adoption of an organizational practice by subsidiaries of multinational corporations: Institutional and relational effects. Academy of Management Journal, 45: 215-233.

*Kostova, T., Roth, K., \& Dacin, M. T. 2008. Institutional theory in the study of multinational corporations: A critique and new directions. Academy of Management Review, 33: 994-1006.

${ }^{*}$ Kriauciunas, A., \& Kale, P. 2006. The impact of socialist imprinting and search on resource change: $A$ study of firms in Lithuania. Strategic Management Journal, 27: 659-679.

${ }^{*}$ Krishnan, R. A., Joshi, S., \& Krishnan, H. 2004. The influence of mergers on firms' product-mix strategies. Strategic Management Journal, 25: 587-611.

Kuhn, T. 1970. The structure of scientific revolutions (2nd ed.). Chicago: University of Chicago Press.

Landis, J. R., \& Koch, G. G. 1977. The measurement of observer agreement for categorical data. Biometrics, 33: 159-174.

Lapakko, D. 1997. Three cheers for language: A closer examination of a widely-cited study of non-verbal communication. Communication Education, 46: 63-67.

Lawrence, T., \& Suddaby, R. 2006. Institutions and institutional work. In S. Clegg, C. Hardy, T. Lawrence, \& W. Nord (Eds.), Handbook of organizational studies: 215-254. London: Sage.

Leblebici, H., Salancik, G. R., Copay, A., \& King, T. 1991. Institutional change and the transformation of interorganizational fields: An organizational history of the U.S. radio broadcasting industry. Administrative Science Quarterly, 36: 333-363.

${ }^{*}$ Lee, G. K., \& Paruchuri, S. 2008. Entry into emergent and uncertain product-markets: The role of associative rhetoric. Academy of Management Journal, 51: 1171-1188.

${ }^{*}$ Lee, K., \& Pennings, J. M. 2002. Mimicry and the market: Adoption of a new organizational form. Academy of Management Journal, 45: 144-162.

Levitt, B., \& Nass, C. 1989. The lid on the garbage can: Institutional constraints on decision making in the technical core of college-text publishers. Administrative Science Quarterly, 34: 190-207.

${ }^{*}$ Levy, D. L. 2008. Political contestation in global production networks. Academy of Management Review, 33: 943-963.

${ }^{*}$ Li, J., Lam, K., Sun, J., \& Liu, S. 2008. Strategic human resource management, institutionalization, and employment modes: An empirical study in China. Strategic Management Journal, 29: 337-342. 
Lichtenberg, J. 1992. The new paradox of the college textbook. Change, 24(5): 10-18.

*Lounsbury, M. 2007. A tale of two cities: Competing logics and practice variation in the professionalizing of mutual funds. Academy of Management Journal, 50: 289-307.

*Lounsbury, M., \& Glynn, M. A. 2001. Cultural entreprenuership: Stories, legitimacy, and the acquisitions of resources. Strategic Management Journal, 22: 545-564.

Lumpkin, G. T., \& Dess, G. 1996. Clarifying the entrepreneurial orientation construct and linking it to firm performance. Academy of Management Review, 21: 135-172.

${ }^{*}$ Luo, Y. 2002. Contract, cooperation, and performance in international joint ventures. Strategic Management Journal, 23: 903-920.

*Lynall, M. D., Golden, B. R., \& Hillman, A. J. 2003. Board composition from adolescence to maturity: A multitheoretic view. Academy of Management Review, 28: 416-431.

Lynch, M., \& Bogen, D. 1997. Sociology's asociological "core": An examination of textbook sociology in light of the sociology of scientific knowledge. American Sociological Review, 62: 481-493.

${ }^{\star}$ Marquis, C., Glynn, M. A., \& Davis, G. F. 2007. Community isomorphism and corporate social action. Academy of Management Review, 32: 925-945.

*Matten, D., \& Moon, J. 2008. "Implicit" and "explicit" CSR: A conceptual framework for a comparative understanding of corporate social responsibility. Academy of Management Review, 33: 404-424.

Mayer, R. E. 1989. Models for understanding. Review of Educational Research, 59: 43-64.

${ }^{*}$ McKinley, W., Zhao, J., \& Rust, K. G. 2000. A sociocognitive interpretation of organizational downsizing. Academy of Management Review, 25: 227-243.

${ }^{\star}$ McNamara, G., Deephouse, D. L., \& Luce, R. A. 2003. Competitive positioning within and across a strategic group structure: The performance of core, secondary, and solitary firms. Strategic Management Journal, 24: 161-181.

${ }^{*}$ Mesquita, L. F., \& Lazzarini, S. G. 2008. Horizontal and vertical relationships in developing economies: Implications for SMEs' access to global markets. Academy of Management Journal, 5l: 359-380.

Meyer, J., \& Rowan, B. 1977. Institutionalized organizations: Formal structure as myth and ceremony. American Journal of Sociology, 83: 340-363.

Miner, J. 2002. Organizational behavior: Foundations, theories, analyses. New York: Oxford University Press.

Miner, J. B. 2003. The rated importance, scientific validity, and practical usefulness of organizational behavior theories: A quantitative review. Academy of Management Learning and Education, 2: 250-268.

Mizruchi, M., \& Fein, L. 1999. The social construction of organizational knowledge: A study of the uses of coercive, mimetic, and normative isomorphism. Administrative Science Quarterly, 44: 653-683.

Nag, R., Hambrick, D. C., \& Chen, M.-J. 2007. What is strategic management, really? Inductive derivation of a consensus definition of the field. Strategic Management Journal, 28: 935-955.

Nerur, S. P., Rasheed, A. M. A., \& Natarajan, V. 2008. The intellectual structure of the strategic management field: An author co-citation analysis. Strategic Management Journal, 29: $319-336$.

Norgaard, R. L. 1981. The evolution of business finance textbooks. Financial Management, 10(2): 34-45.

Oliver, C. 1991. Strategic responses to institutional processes. Academy of Management Review, 16: 145-179.

Oliver, C. 1997. Sustainable competitive advantage: Combining institutional and resource-based views. Strategic Management Journal, 18: 697-711.

Paul, D. B. 1988. The market as censor. Political Science and Politics, 21: 31-35.

Pearce, J. A., \& Robinson, R. B. 2000. Strategic management: Formulation, implementation, and control (7th ed.). Chicago, IL: R. D. Irwin, Inc.

Pearce, J. A., \& Robinson, R. B. 2009. Strategic management: Formulation, implementation, and control (llth ed.). New York: McGraw-Hill Irwin.

*Peng, M. W. 2004. Outside directors and firm performance during institutional transitions. Strategic Management Journal, 25: 453-471.

*Peng, M. W., Lee, S.-H., \& Wang, D. Y. L. 2005. What determines the scope of the firm over time? A focus on institutional relatedness. Academy of Management Review, 30: 622-633.

Peng, M. W., Sun, S. L., Pinkham, B., \& Chen, H. 2009. The institution-based view as the third leg for a strategy tripod. Academy of Management Perspectives, 23: 63-81.

${ }^{*}$ Pfarrer, M. D., Decelles, K. A., Smith, K. G., \& Taylor, M. S. 2008. After the fall: Reintegrating the corrupt organization. Academy of Management Review, 33: 730-749.

Pfeffer, J. 1993. Barriers to the advance of organizational science: Paradigm development as a dependent variable. Academy of Management Review, 18: 599-620.

Pfeffer, J., \& Fong, C. T. 2004. The business school 'business': Some lessons from the U.S. experience. Journal of Management Studies, 41: 1501-1520.

Phillips, N., Lawrence, T., \& Hardy, C. 2004. Discourse and institutions. Academy of Management Review, 29: 635-652.

Porter, M. E. 1980. Competitive strategy: Techniques for analyzing industries and competitors. New York: The Free Press.

Powell, W. W. 1980. Economic trends in the print industry competition versus concentration in the book trade. Journal of Communication, 30: 89-97.

Ramos-Rodríguez, A.-R., \& Ruíz-Navarro, J. 2004. Changes in the intellectual structure of strategic management research: A bibliometric study of the Strategic Management Journal, 1980-2000. Strategic Management Journal, 25: 981-1004.

Rao, H. 1994. The social construction of reputation: Certification contests, legitimation, and the survival of organizations in the American automobile industry: 1895-1912. Strategic Management Journal, 15: 29-44.

Rotfeld, H. J. 2000. The textbook effect: Conventional wisdom, myth, and error in marketing. Journal of Marketing, 64: 122-127.

Rousseau, D. 2006. 2005 presidential address: Is there such $a$ thing as "evidence-based management"? Academy of Management Review, 31: 256-269.

Rousseau, D. M., \& McCarthy, S. 2007. Educating managers from an evidence-based perspective. Academy of Management Learning and Education, 6: 84-101. 
${ }^{*}$ Russo, M. V. 2001. Institutions, exchange relations, and the emergence of new fields: Regulatory policies and independent power producing in America, 1978-1992. Administrative Science Quarterly, 46: 57-87.

${ }^{*}$ Sanders, W. G., \& Tuschke, A. 2007. The adoption of institutionally contested organizational practices: The emergence of stock option pay in Germany. Academy of Management Journal, 50: 33-56.

Schneiberg, M., \& Clemens, E. 2006. The typical tools for the job: Research strategies in institutional analysis. Sociological Theory, 24: 195-227.

Scott, W. R. 2007. Institutional theory: Contributing to a theoretical research program. In K. A. Smith \& M. A. Hitt (Eds.), Great minds in management: The process of theory development: 460-484. Oxford: Oxford University Press.

Scott, W. R., \& Davis, G. F. 2007. Organizations and organizing: Rational, natural, and open systems perspectives. Upper Saddle River, NJ: Pearson Education.

Selznick, P. 1957. Leadership in administration. Evanston, IL: Row Peterson.

Shapin, S. 1995. Here and everywhere: Sociology of scientific knowledge. Annual Review of Sociology, 21: 289-321.

${ }^{*}$ Sine, W. D., Haveman, H. A., \& Tolbert, P. S. 2005. Risky business: Entrepreneurship in the new independent-power sector. Administrative Science Quarterly, 50: 200-232.

${ }^{*}$ Steensma, H. K., Tihanyi, L., Lyles, M. A., \& Dhanaraj, C. 2005. The evolving value of foreign partnerships in transitioning economies. Academy of Management Journal, 48: 213-235.

*Suddaby, R., \& Greenwood, R. 2005. Rhetorical strategies of legitimacy. Administrative Science Quarterly, 50: 35-67.

${ }^{*}$ Suddaby, R., Elsbach, K., Greenwood, R., Meyer, J., \& Zilber, T. B. 2007. Organizations and their institutional environments: Bringing meaning, culture, and values back in. Academy of Management Journal, 50: 468-469.

Sutcliffe, K. M., \& Wintermute, T. P. 2006. Gladwell as sensegiver. Journal of Management Inquiry, 15: 404-405.

Thompson, A. A., Gamble, J. E., \& Strickland, A. J. 2006. Strategy: Winning in the marketplace (2nd ed.). New York: McGrawHill Irwin.

Thompson, A. A., Strickland, A. J., \& Gamble, J. E. 2008. Crafting and executing strategy: The quest for competitive advantage (16th ed.). New York: McGraw-Hill Irwin.

Thornton, P. H., \& Ocasio, W. 1999. Institutional logics and the historical contingency of power in organizations: Executive succession in the higher education publishing industry, 1958-1990. American Journal of Sociology, 105: 801-843.

Tompkins, J. P. 1980. Reader-response criticism: From formalism to post-structuralism. Baltimore, MD: Johns Hopkins University Press.

Trank, C. Q., \& Rynes, S. L. 2003. Who moved our cheese? Reclaiming professionalism in business education. Academy of Management Learning and Education, 2: 189-205.

*Vaara, E., \& Tienari, J. 2008. A discursive perspective on legitimation strategies in multinational corporations. Academy of Management Review, 33: 985-993.

Walker, G. 2007. Modern competitive strategy (2nd ed.). New York: McGraw-Hill Irwin.

Walsh, J., Meyer, A. D., \& Schoonhoven, C. B. 2006. A future for organization theory: Living in and living with changing organizations. Organization Science, 17: 657-671.

*Westphal, J. D., \& Zajac, E. J. 2001. Decoupling policy from practice: The case of stock repurchase programs. Administrative Science Quarterly, 46: 202-229.

Wheelen, T. L., \& Hunger, J. D. 2008. Strategic management and business policy: Concepts (1lth ed.). Upper Saddle River, NJ: Pearson Education.

*Williamson, I. O., \& Cable, D. M. 2003. Organizational hiring patterns, interfirm network ties, and interorganizational imitation. Academy of Management Journal, 46: 349-358.

Woolgar, S. 1981. Interests and explanations in the social study of science. Social Studies of Science, 11: 365-394.

${ }^{*} X u$, D., \& Shenkar, O. 2002. Institutional distance and the multinational enterprise. Academy of Management Review, 27: 608-618.

*Yin, X., \& Shanley, M. 2008. Industry determinants of the "merger versus alliance" decision. Academy of Management Review, 33: 473-491.

Zbaracki, M. 1998. The rhetoric and reality of Total Quality Management. Administrative Science Quarterly, 43: 602-636.

Jeffrey E. Stambaugh received his PhD from Texas Tech University in 2008. He is an assistant professor at Midwestern State University and directs the Munir Abdul Lalani Center for Entrepreneurship in the Dillard College of Business. His research interests involve the intersection of competitive dynamics and entrepreneurship.

Christine Quinn Trank received her PhD in 2001 from the University of Iowa, and is on the faculty in the Area of Management of Texas Tech University. Her research interests focus on the institutional context of business education and on processes and effects of symbolic activity in organizations. 
Copyright of Academy of Management Learning \& Education is the property of Academy of Management and its content may not be copied or emailed to multiple sites or posted to a listserv without the copyright holder's express written permission. However, users may print, download, or email articles for individual use. 